\title{
20 YEARS OF PROGRESS: HOW THE REGIONAL WATER RESOURCES PROGRAM IN THE PACIFIC NORTHWEST (USA) REDUCED WATER POLLUTION
}

\author{
ROBERT L. MAHLER ${ }^{1}$, MICHAEL E. BARBER ${ }^{2}$ AND ROBERT C. SIMMONS ${ }^{3}$ \\ ${ }^{1}$ Department of Soil and Water Systems, University of Idaho, USA \\ ${ }^{2}$ Department of Civil and Environmental Engineering, University of Utah, USA, \\ ${ }^{3}$ Washington State University Extension, USA
}

\begin{abstract}
In 1998, the Pacific Northwest Water Resources Program was established in the four Pacific Northwest states (Alaska, Idaho, Oregon, Washington) with the ultimate goal of increasing public awareness about water quality and encouraging the public to take voluntary individual actions that would enhance water resources. Prevention of water pollution was the overall primary goal of this 20 -year effort. The outreach arm of the land grant universities in the region led this effort. This effort was made possible by funding provided by the federal, state and local governments as well as non-governmental organizations. This project had short-term, medium-term and long-term goals. The short-term goals were to: (1) improve citizen knowledge about water issues, (2) improve awareness of the capabilities of land-grant universities to address water issues and (3) improve public awareness of and motivation to individually or collectively address water issues. The medium-term goals were to: (1) improve cooperation for educational programming between states, (2) improve partnerships between both public and private, and local, state and regional organizations, (3) encourage citizens to voluntarily make choices to protect water resources and (4) help policy makers enact legislation to enhance the quality and quantity of water resources. The long-term goal of the regional project was to improve the quality of water resources within the four-state region. Water quality education was delivered to local citizens using public meetings, workshops, printed pamphlets, Internet-based publications, video-conferences and mass media. There was a strong education-research partnership component to this program. Large regional surveys were conducted initially and then every 5 years to understand citizen attitudes, priorities and individual actions taken to protect water quality in the region. The survey results showed that over the term of the project the public had become more engaged in reducing water pollution. This regional program made the public both more aware of potential pollution problems and encouraged citizens to be a part of the solution to water pollution. Although it is difficult to directly measure water quality improvement on a regional basis, project surveys showed that compared to 2002 over $75 \%$ of the public have taken individual actions to improve water quality. Positive actions have included: (1) a change in the disposal of household chemicals, (2) a reduction in the use of pesticides and fertilizers in urban areas and (3) better maintenance of septic systems in rural areas.
\end{abstract}

Key words: public concerns, public opinion, water quality, water issues, water quality improvement.

\section{BACKGROUND}

Alaska, Idaho, Oregon and Washington comprise the four states in the northwestern region of the USA. Collectively, these states account for $26 \%$ of the land area in the USA but contain only 13,000,000 people (4\% of the total population). As a region the Pacific Northwest is water-rich and water quality is considered to be a more difficult environmental problem than water quantity. Even though the population is small, this is the fastest growing region in the USA. Consequently, activities associated with growth will be an even greater challenge to water quality in the future. 


\section{INTRODUCTION}

The Earth's fresh water supply is finite and small compared to the total amount of water present on the planet. Studies sponsored by the United Nations suggest that each human requires in excess of 900,000 L of water each year to meet their needs [1,2]. This includes water used for food production, sanitation, drinking, food preparation and hygiene. Even though there is currently adequate fresh water to meet human needs on a worldwide basis, current water quality sufficiency is not met on a country-by-country basis. As the human population grows from 7,750,000,000 toward 9,000,000,000 people by 2040 fresh water shortages will become more widespread $[3,4]$.

Much of the fresh water in the Pacific Northwest region falls as mountain snow in the colder months of the year. This water is stored as snowpack in the winter and when temperatures warm up in April, May and June it melts and flows down rivers and streams where it can be captured to support economic activity within the region. The snowpack, through rivers and indirectly through groundwater recharge, provides irrigation water for over 3,000,000 ha of agricultural land. In addition, over $60 \%$ of the USA's hydropower is produced from water flowing through the region's dams. The rivers support the transport of economic goods and provide numerous recreational activities for residents. Indirectly and directly, the mountain snows provide drinking water, wetland habitat and a favourable aquatic habitat that provides both good water quality and a sufficient quantity of water to meet the needs of the people that reside in these four states.

Water and soils are the most important natural resources in the USA. Water quality became a much more important issue for the American public in the 1980s when president George H. Bush created a National Water Quality Initiative [5]. Because of this initiative many federal agencies directed additional resources to enhance water quality. Consequently, since 1990 water quality has been a priority topic for the United States Department of Agriculture (USDA) and extension (outreach). Even with an increased emphasis and additional monetary resources flowing to states for water quality educational programming, many state universities (land grant institutions, LGIs) were not able to adequately address water education needs in most states. Consequently, the USDA decided to emphasize regional water quality programming rather that individual state programming by the late 1990s. The idea behind regional programming was that states could share expertise with limited funds. Thus, for instance, one state in the region could hire staff to educate about protecting water quality from animal waste, while another state could hire staff to protect water quality from soil erosion. Both states could then share these staff to provide adequate programming for all states in the region.

To encourage regional water quality programming the USDA made more than $\$ 50,000,000$ available over a 12 -year period for regional water quality programming to LGIs on a competitive basis. Thus, regional water quality programming projects were created. The federal funding became available in 2000 and lasted until 2012. The Pacific Northwest Region (Alaska, Idaho, Oregon, Washington) received a portion of the available funds. Even though funding officially ended in 2012 state and local funds were used to continue programming of high priority topics until 2018. The Pacific Northwest Region used federal, state and local funds to provide water quality programming in the following eight national water quality theme areas: (1) animal waste management, (2) drinking water and human health, (3) environmental restoration, (4) nutrient and pesticide management, (5) pollution assessment and prevention, (6) watershed management, (7) water conservation and (8) water policy and economics. The Pacific Northwest Region Project also developed programming in a ninth area - stormwater 
management. Over the period of federal funding the program also added a water quantity education component. This report is a summary of how the Pacific Northwest Regional Water Quality Program reduced water pollution in the last 20 years.

\section{METHODOLOGY}

The Pacific Northwest Water Quality Team formed in 1998 and consisted of the following nine member positions: (1) water quality coordinator from the University of Alaska, (2) water quality coordinator from the University of Idaho, (3) water quality coordinator from Oregon State University, (4) water quality coordinator from Washington State University, (5) water quality coordinator from Northwest Indian College, (6) the director State of Washington Water Research Center (SWWRC) at Washington State University, (7) the LGI liaison stationed at Environmental Protection Agency (EPA) Region 10 Headquarters in Seattle, WA, (8) a representative from the United States Natural Resources Conservation Service (USDA-NRCS) and (9) a representative from EPA Region 10. This team met quarterly at the EPA Region 10 headquarters in Seattle, WA. Although not geographically in the centre of the region, the Seattle location had convenient airline connections for all team members. A regional advisory committee was developed to provide input to the regional team [6].

The regional water quality program consisted of seven major programming mechanisms. These programming mechanisms were: (1) live satellite conferences to support local citizenled watershed groups, (2) development and delivery of two newsletters targeted to educators and decision makers, (3) development and delivery of regional research and extension conferences about relevant water resources topics, (4) the enhancement of land-grant universities water resource education capacity, (5) development of thematic regional expertise directories, (6) a needs assessment survey and (7) surveys developed to measure public knowledge, attitudes and actions taken to directly to impact water resources.

Satellite conferences. Steering committees consisting of representatives from land grant universities, local, state and federal agencies, watershed groups and private water interests developed topic themes for regional conferences. The steering committee oversaw the content, logistics, evaluation process and selected speakers and facilitators for each conference. Many counties in the four-state region had a satellite downlink site at the local extension office that could be used for each conference. A total of nine water-based conferences were delivered using this technology.

Water Update Newsletters. The Pacific Northwest Regional Water Quality Team developed a series of newsletters about water quality issues for citizens of the region. The team developed a list of topics and assigned university faculty to write two page articles about each selected topic. Each newsletter article consisted of approximately 700 words and was illustrated with colour photographs. The regional team produced the newsletters and distributed them using the regional web page and by regular mail to specific target audiences. Two newsletters were produced each month.

Regional Research and Extension Conferences. The Pacific Northwest Regional Water Quality Team developed and conducted six major water-themed regional research and extension conferences conducted at a central site in the region over a 10-year period. The regional team along with personnel from local, state and federal agencies developed the themes and a call for presented papers from partner organizations. The purpose of the conferences was to create a greater link between professional educators and researchers within the four-state region.

Enhancement of Education Capacity. A regional web site was created to house all newsletters, publications, expertise directories and educational opportunities relating to water quality 
for both LGI staff and the public. Workshops were developed on specific water topics for staff as suggested by steering committees. The overall project advisory committee provide input and suggestions for enhancing the educational capacity of LGI staff.

Development of Expertise Directories. Expertise directories for the project's nine programing areas were developed as newsletters and the directories were available in the PNW web site and to all county extension offices in the region.

Needs Assessment Survey. In 2002, a needs assessment survey consisting of 60 questions was developed and sent to 2,000 randomly chosen residents of the region. Over $52 \%$ of the citizens receiving the scientifically conducted survey responded. The survey results were used to prioritize water quality programming in the region over the duration of the project.

Measurement of Public Attitudes and Actions Taken to Address Water Quality. Follow-up surveys to the 2002 needs assessment were conducted at 5 (2007), 10 (2012) and 15 years (2017) to measure changes in public literacy, attitudes and actions taken by individuals to address water issues. These surveys were mail-based, large (2,000+ participants), scientifically conducted and statistically analysed.

\section{RESULTS AND DISCUSSION}

Many different programming mechanisms were used in this regional project; however, only seven mechanisms are discussed below. In the 20 years of this regional project over 215 LGI faculty and staff were actively involved. Over 90,000 citizens directly received this regional programming. When the indirect contacts (through newsletters, magazine articles, web sites, newspaper, magazine articles, etc.) are counted a total of 4,740,000 people received information and/or programming from this project. This number equates $40.6 \%$ of the adult population of the four states. A summary of the seven major programming mechanisms, references and accomplishments are shown below.

\subsection{Satellite conferences}

The Pacific Northwest Water Quality Team developed a series of nine regional (Alaska, Idaho, Oregon, Washington) watershed issues down-linked conferences that were delivered in 2002, 2003, 2004, 2005, 2006, 2007, 2008, 2009 and 2010 using existing state-of-the-art technology and a regional steering committee. These satellite conferences were down-linked to a minimum of 38 educational sites each year with an annual attendance ranging from 318 to 5,589 educators, agency and non-profit personnel and members of local watershed groups. Attendance at these conferences started at 318 in 2002 and increased every year until 2010 when 5,589 people attended the satellite conference. Evaluations completed by attendees indicated that regional programming was an efficient and effective alternative to individual state programming efforts.

In the 9-year run of these satellite conferences the steering committee selected topics of interest to target audiences. Examples of satellite conference topics included: (1) Living on the Edge: Grassroots Watershed Planning in the Pacific Northwest, (2) Funding Watershed Restoration, (3) Improving Community Involvement in Watersheds, (4) Stormwater Management from a Watershed Perspective, (5) Stormwater Management: One Back Yard at a Time and (6) Stormwater Management in Extreme Climates of the Western USA.

The high quality of the watershed issues regional conferences has been affirmed by increasing attendance, high evaluation scores by attendees, partnerships that have endured and strengthened, and a national award from educational peers [7]. The success of the regional 
water conferences suggests that in the future less attention should be paid to state boundaries and more concentration on regional audiences can make a significant difference in the effective management of natural resources. The use of satellite conferences was discontinued in 2011 because advances in technology allowed citizens to view programs and interact effectively on their personal computers. Thus, people could still virtually attend conferences and interact with other interested people; however, the expensive satellite technology, room rentals, scheduling needs and individual hosts at specific sites were no longer needed.

\subsection{Water update newsletters}

Regional two-page newsletters that focused on water issues were developed to educate clientele. Over 265 newsletter issues were produced between 2002 and 2013 (Fig. 1). The newsletter called PNWWATER UPDATE, was produced in colour was issued twice a month [8]. The frequency of issue was important because it let citizens know about the many water programs and activities in the region and it kept the topic of water in front of them. The newsletter was posted on the regional web site and sent by mail to 600 stakeholders in the region including: (1) the Congressional delegation from the four Pacific Northwest states, (2) all state legislators serving on education, environment or agriculture committees, (3) LGI administrators, (4) members of the USDA-CSREES (now National Institute of Food and Agriculture, NIFA) executive team, (5) administrators in partner federal, state and local agencies, (6) county extension offices and (7) high school science teachers. The policy makers consisted of Congressional and state legislators. Fifty-seven policy makers (50\% of the 114 that received evaluation surveys from the PNW team) on mailing lists for at least 3 years evaluated the value of this newsletter. In general, policy makers found these frequently issued newsletters to be of high quality, timely, informative and that the newsletters addressed water quality priorities in the region.

In general, policy makers who completed the evaluation form had positive things to say about the PNWWATER UPDATES; 33\%, 30\%, 33\% and $4 \%$ of the respondents reported that they always, often, sometimes or never read the updates mailed to them, respectively. The fact that $96 \%$ of the policy makers at least occasionally read the produced newsletter was encouraging.

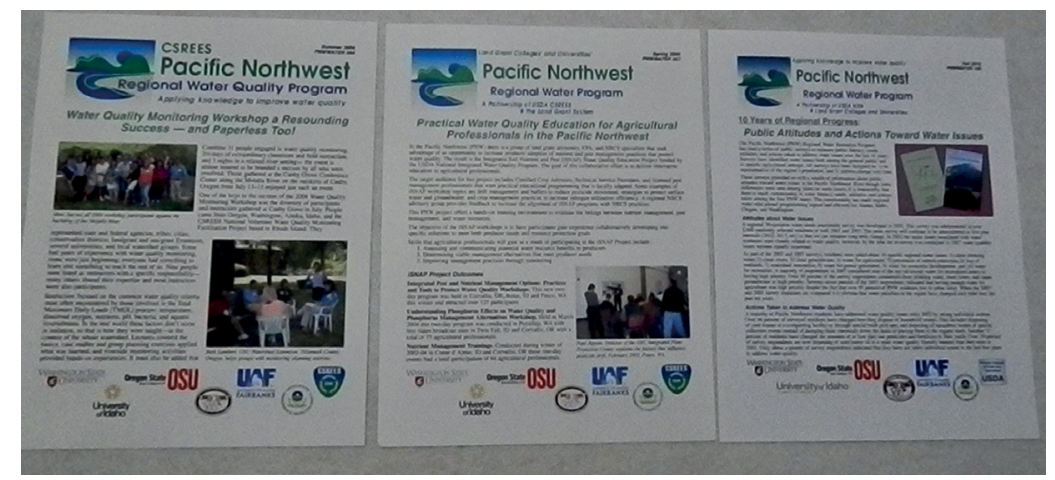

Figure 1. Examples of three PNWWATER UPDATES produced by the Regional Water Quality Team as newsletter. 
Over $88 \%$ of the responding policy makers reported that they wanted to continue to receive the newsletter. The types of information of most interest to policy makers varied; however, a majority of respondents expressed interest in updates highlighting water quality, success stories, current program efforts and water quantity.

A survey of all recipients of newsletters indicated that $73 \%$ found the quality of the newsletter to be excellent. The same percentage also felt that the updates were about the right length. Over $81 \%$ of respondents reported that prior to receiving PNWWATER UPDATES they knew virtually nothing or much less than they do now about water programs at land grant universities. Over two-thirds of update recipients approved of the one sheet, colour format. Only seven respondents would have preferred a web-based format newsletter. Based on citizen input the traditional paper copy was handier, effective and more likely to be read to convey water information to policy makers than via electronic transmission.

\subsection{Regional research and extension conferences}

Six major water themed regional research and extension conferences were conducted over a 10-year period. The conference themes were determined by an inter-agency steering committee led by the regional team. The goal of the conferences was to provide cutting edge research, education and outreach strategy information on priority water issues to water resource professionals. Conference themes were as follows: (1) 2002 - Water Quality: The Importance of Research and Extension, (2) 2003 - Groundwater Under the Pacific Northwest, (3) 2005 - Integrating Research, Policy and Education for our Groundwater Resources, (4) 2007 - Water in the Pacific Northwest: Moving Science into Policy and Action, and (5) 2009 - Water and Land Use in the Pacific Northwest: Integrating Communities and Watersheds and (6) 2011 - Water in the Columbia Basin.

Each of the six conferences had keynote presentations and a call for papers that were screened by the conference steering committee. Approximately 50 volunteer papers were presented at each conference. These volunteer papers came from scientists at land grant universities, state and federal agencies, non-profit organizations (NGOs), soil and water conservation districts and the private sector. To encourage graduate student participation a student poster competition was also conducted, and monetary awards were given to students with the best posters. The conferences were an important meeting place for professionals to meet and exchange ideas about water quality protection and enhancement. The positive impact of these conferences endures as partnerships between scientists and agencies were forged and continue to be active.

The regional conferences were well-attended as between 190 and 295 delegates attended each of the six major conferences. Evaluations by conference attendees were very positive and evaluators cited the need for additional conferences in the future. In addition to the major regional conferences many additional smaller conferences were sponsored by the regional team. Topics of smaller conferences included: (1) Using Integrated Pest Management in Agriculture, (2) Animal Waste Management Issues Affecting Water Quality, (3) Soil Erosion and Its Impact on Surface Water Quality, (4) Rain Gardens - Localized Storm Water Management and (5) Nutrient Management and Water Quality.

\subsection{Enhancement of education capacity}

A regional web site was created to house all materials developed about water quality for the LGI educators and the general public. Materials housed on the regional web site included 
newsletters, publications, expertise directories and educational opportunities relating to water quality for both LGI staff and other professionals. Throughout the duration of the project workshops were developed on specific water quality topics for staff as suggested by steering committees. These workshops were well-attended by LGI staff and other professionals. Voluntary monitoring programs were conducted for citizens interested in the quality of stream, lakes and beaches.

Large notebooks on specific water quality issues were compiled and placed in all county extension offices. An example of a compiled notebook was a domestic water handbook called - Domestic Water Use - A Resource Guide for Extension. These notebooks were placed in county extension offices and contained 14 chapters and 70 appropriate publications from the region and across the country. These publications were written by drinking water experts at LGIs, state and local health departments and federal agencies. These handbooks were revised annually and by being at county extension offices the information was readily available to educators and the general public. In addition to the paper copies of the notebooks all materials were available on compact disks.

A natural resources curriculum was developed for Native Americans in the region. Northwest Indian College took the lead on this water-based program. Linkages between LGIs and other projects also enhanced the education capacity in the region. Examples of important linkages established between the Regional Water Quality Program and other groups included: (1) Integrated Pest Management (IPM) programs in the region, (2) the Western Integrated Pest Management Center, (3) nutrient management programs in the region, (4) the regional confined animal feeding operation (CAFO)/Animal Water Program, (5) the Puget Sound Partnership, (6) Sea Grant Institutions in Washington, Oregon and Alaska, (7) iSNAP (nutrient and pesticide education) and (8) the Idaho Conservation Effectiveness Program (CEAP).

\subsection{Regional expertise directories}

Nine regional expertise directories representing the nine water quality programming areas were produced. These directories contained the following information for each expertise topic: (1) the importance of the topic for water quality protection, (2) the desired water quality outcomes for each pollutant source, (3) a list of current and relevant publications that could be obtained from LGIs, (4) contact information for LGI educators/researchers having specific expertise in each state and (5) information about the regional project. Examples of regional expertise directories are shown in Fig. 2. The expertise directories were widely circulated, produced as PNWWATER UPDATES, updated on an annual basis, and were also housed on the regional web site.

\subsection{Needs assessment survey}

In 2002, a 60-question needs assessment survey was developed and sent to 2,300 randomly chosen adults in the region. The mail-based survey received a $52 \%$ response rate. Detailed logistics of this survey have been published elsewhere $[9,10,11]$. The survey gave the regional team a snapshot of the current knowledge and aptitudes the public possessed about water quality issues in the region. The data provided a template for water quality programming needs in the region from 2002 to 2018.

From a drinking water standpoint the assessment survey found the following: (1) over $90 \%$ of survey respondents felt that their home drinking water was safe for consumption, (2) minerals were considered the most common drinking water contaminants, (3) about $25 \%$ of 


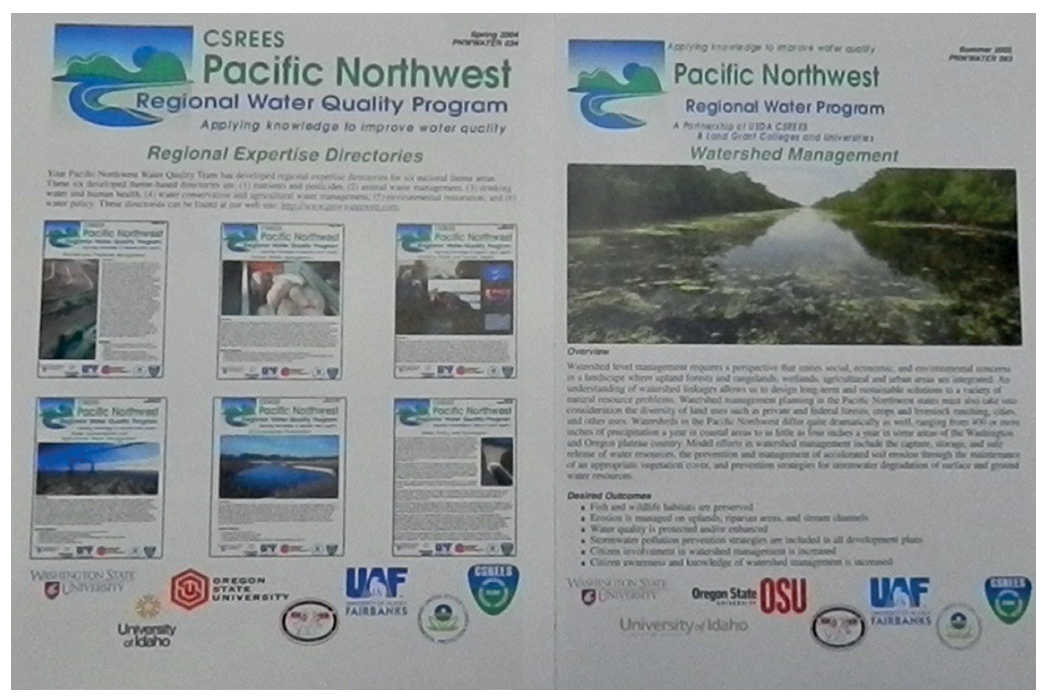

Figure 2. Examples of regional expertise guides produced by regional water quality team for distribution to extension offices and the general public.

residents have installed a secondary filter on their drinking water system and (4) about $25 \%$ of residents used bottled water for drinking [10]. The needs survey showed that the public wanted more information about drinking water quality and protection.

Needs assessments indicated that over $90 \%$ of the regions' citizens considered clean drinking water, clean groundwater and clean rivers very important issues [9]. Other water issues considered important by over $60 \%$ of survey respondents included: (1) wetland protection, (2) watershed restoration, (3) water for power generation, (4) water for agriculture, (5) prevention of salmon extinction and (6) having enough water for economic development. These results suggested that regional water quality education efforts should concentrate on these issues.

In 2002 most people relied on newspapers (68\%), television (59\%) and environmental agencies $(51 \%)$ for water quality information [11]. Universities $(25 \%)$, the Internet $(15 \%)$ and schools $(20 \%)$ were less important sources of water quality information. The needs assessment suggested that LGIs educational campaigns concentrate on media sources that were most important to the public.

The 2002 needs assessment survey was used as a model and was adopted by six other water quality programming regions in the USA [12]. The true value of this needs assessment was twofold: First, the survey results directed water quality programming efforts in the region. Second, the results were used as base line data that could be compared to results of future surveys conducted in the region.

4.7 Measurement of public attitudes and actions taken to address water quality

Follow-up surveys to the initial needs assessment survey conducted in 2002 were made at 5-year intervals in 2007, 2012 and 2017. The questions in these surveys were 70\% identical 
Table 1: Percentage of survey respondents who have taken a voluntary action to protect water quality and water quantity based on responses to 2002 and 2017 surveys.

\begin{tabular}{lllll}
\hline Water & Action & $2002 \%$ & $2017 \%$ & Significance \\
\hline \multirow{6}{*}{ Water quality } & Home waste disposal & 24.9 & 64.4 & 0.0001 \\
& Pesticide/fertilizer use & 17.9 & 56.6 & 0.0001 \\
& Motor oil disposal & 19.7 & 77.9 & 0.0001 \\
& No action taken & 44.9 & 18.6 & 0.0001 \\
\multirow{5}{*}{ Water quantity } & Installed water saving appliance & 40.6 & 79.2 & 0.0001 \\
& Changed yard watering & 28.9 & 54.7 & 0.0001 \\
& Changed household water use & 32.4 & 67.3 & 0.0001 \\
& Changed vehicle washing & 26.7 & 36.8 & 0.0001 \\
& No actions taken & 28.9 & 11.4 & 0.0001 \\
\hline
\end{tabular}

to the 2002 survey and about $30 \%$ of the survey was composed of questions not previously asked. The identical questions allowed the team to determine changes in public attitudes and actions taken to address water resource issues.

Because it is almost impossible to measure changes in regional water quality, the team measured changes the public took to individually address water issues. Public actions used to address water issues in 2002 and 2017 are shown in Table 1. In general, a larger majority of the public had taken individual actions to address water quality and quantity issues in 2017 compared to 2002 [13]. Statistically significant differences for public actions were observed for all water quality and quantity issues between 2002 and $2017(p<0.0001$ in all comparisons). The data in this table show that the public had taken actions to proactively address water resource issues in this project time period.

Several other things occurred between 2002 and 2017 in the region that were important in improving water quality. First, by 2017 the Internet had become the most important source of water quality information to the public, while newspapers, television and workshops became less important. The use of bottled water for drinking purposes decreased; due to citizens being made aware that tap water was safe and the desire to decrease the use of disposable plastic water bottles.

The observations above can be attributed to the educational programs about water quality provided by the Regional Water Quality Team. Other agencies and non-profit organizations also contributed to the increased water literacy of the public; however, the coordinated regional water quality project was able to capture some of the educational momentum provided by these agencies through the use of newsletters and web sites.

\section{CONCLUSIONS AND RECOMMENDATIONS}

The regional project was a massive undertaking that involved over 200 educators and millions of residents in the Pacific Northwest. The regional team has listed and discussed below what they consider to be the important products and outcomes of this 20 -year project. 


\subsection{Products produced}

The Pacific Northwest Regional Water Quality Team produced many products that were developed to enhance learning about water quality within the region. Notable products include:

- Nine water quality themed satellite conferences that over a 9-year period attracted a live audience of 27,936 people. Many additional people viewed the tapes of the conferences.

- 265 PNWWATER UPDATE newsletters were produced and circulated via both paper copies and on the regional web site.

- Six major water quality themed research and extension conferences were conducted. Registered attendance exceeded 1,300 people.

- A regional web site on water quality within the Pacific Northwest region was developed. Over 110,000 site visits were recorded between 2002 and 2014.

- Nine regional expertise directories were produced covering the following topics: (1) nutrient and pesticide management, (2) drinking water and human health, (3) animal waste management, (4) stormwater management, (5) environmental restoration, (6) pollution assessment and prevention, (7) watershed management, (8) water conservation and management and (9) water policy and economics.

- In 2002, a public needs assessment survey was conducted to serve as a template for educational priorities in the region.

- Public surveys were conducted in 2007, 2012 and 2017 to measure public attitudes and actions taken to address water quality.

- Over 2,000 different educational materials were produced from this program. Twelve journal articles related to this effort were also produced.

\subsection{Water quality successes}

The Pacific Northwest Regional Water Quality Project was unable to quantify an improvement in water quality in the region; however, significant change/progress can be quantified over the 20-year project period in three ways. The following three indicators point to improved water quality in the region in the last 20 years and also provide evidence that water quality will continue to improve in the future:

First, public surveys conducted in 2007, 2012 and 2017 indicated that many people took individual, voluntary actions to positively address water issues. In fact, over $81 \%$ of the adult public took at least one action to positively impact water quality. While individual actions by themselves are tiny, they do add up and when millions of people make changes - water quality does improve. Another positive aspect of voluntary change is that people became proactive about water quality and were not waiting around for regulatory activity to solve all water problems.

Second, over 90,000 citizens actively attended educational programs on water quality provided by the regional water quality program over 20 years. Many of these people actively sought out water quality education and used their acquired knowledge to improve water resources in their homes and communities.

Third, the project's penetration was remarkable. Over $40.6 \%$ of the adults in Alaska, Idaho, Oregon and Washington were directly or indirectly reached by the educational programs. This is a very high public penetration rate for a large population - unmatched in the scientific literature. This program built an awareness of water quality for over $40 \%$ of the population. 
If, as suggested by surveys, $81 \%$ of the public took even a small action to positively improve water quality - these small actions add and multiply to a significant improvement in water quality over this 20 -year period and in the near future.

\section{ACKNOWLEDGEMENTS}

We would like to acknowledge USDA-NIFA for their project support, specifically project 2008-51130-04734.

\section{REFERENCES}

[1] Arnell, N.W., van Vuuren, D.P. \& Isaac, M. The implications of climate policy for the impacts of climate change on global water resources. Global Environmental Change. 21, pp. 592-603, 2011. doi: http://dx.doi.org/10.1016/j.gloenvcha.2011.01.015

[2] Postel, S.L., Daily, G.C. \& Ehrlich, P.R. Human appropriation of renewable fresh water. Science, 271, pp. 785-788, 1996. doi: http://dx.doi.org/10.1126/science.271.5350.785

[3] Gleick, P.H., The human right to water. Water Policy, 15, pp. 487-503, 1998. DOI: 10.1016/S1366-7017(99)00008-2.

[4] Chenoweth, J.L., Minimum water required for social and economic development. Desalinization, 229, pp. 245-256, 2008. DOI: 10.10016/j.desal.2007.09.011.

[5] Shepard, R., Evaluating extension-based water resource outreach programs: are we meeting the challenge? Journal of Extension [On-line], 40(1). 2002. Available at: http:// joe.org/joe/2002february/a3.html

[6] Agricultural Publications., Water quality efforts in the Pacific Northwest - applying knowledge to improve water quality. University of Idaho College of Agriculture Publications, 2004. 12 pages.

[7] Mahler, Robert L., Seago, Jan, Simmons, Robert, and Scott Fedale. Using satellite broadcasts to educate the public about watershed issues on a regional basis. Journal of Extension [On-line], 46(3). Article 3FEA5. Available at: http://www.joe.org/ joe/2008june/3fea5.php 2008.

[8] Mahler, Robert L., Simmons, Robert, Sorensen, Fred, Cochrane, Michael, and Gail Glick Andrews. Using updates to educate policy makers about water programs at landgrant institutions. Journal of Extension \{On-line], 44(5). Article 5IAW5. Available at: https://www.joe.org/joe/2006october/iw5.php 2006

[9] Mahler, R. L., Simmons, R., Sorensen, F., \& Miner, J.R., Priority water issues in the Pacific Northwest, Journal of Extension [On-line], 42(5). Article 5RIB3. Available at: http://www.joe.org/joe/2004october/rb3.php 2004.

[10] Mahler, R. L., Simmons, R., \& Sorensen, F., Drinking water issues in the Pacific Northwest. Journal of Extension, 43(6): 6RIB6, online at: http://www.joe.org/ joe/2005december/rb6.php 2005.

[11] Mahler, R.L., Gamroth, M., Pearson, P., Sorenson, F., Barber, M.E. \& Simmons, R., Information sources, learning opportunities and priority water issues in the Pacific Northwest, Journal of Extension [On-line], 48(2). Article 2RIB2. Available at: http://www. joe.org/joe/2010april/rb2.php, 2010.

[12] Mahler, Robert L., Michael D. Smolen, Tatiana Borisova, Diane E. Boellstorff, Damian C. Adams \& Nicola W. Sochacka. 2013. The national water survey needs assessment program. Natural Sciences Education 42:98-103. doi:10.4195/nse.2012.0025.

[13] Mahler, Robert L. \& Barber, M.E. Using adult education to improve the sustainability of water resources in the Pacific Northwest, USA. International Journal of Sustainable Development and Planning. Volume 10(6): 828-842, 2015. 